\title{
Diagnosis and modelling of a summer convective storm over Mediterranean Pyrenees
}

\author{
A. Callado and R. Pascual \\ Centre Meteorològic Territorial a Catalunya of Instituto Nacional de Meteorología, Barcelona, Spain \\ Received: 24 October 2004 - Revised: 30 May 2005 - Accepted: 6 June 2005 - Published: 5 August 2005
}

\begin{abstract}
Over the Mediterranean Pyrenees and near coastal region there is a high frequency of convective storms during summertime. This fact determines a local maximum of precipitation at this season unlike the normal and general minimum over Mediterranean basin.

The common synoptic and mesoscale patterns associated to convective phenomena are briefly analyzed and diagnosed with radar imagery, surface pressure and isobaric level fields and surface data. They usually involves a little distant through at medium levels, very weak pressure gradient at the surface and not significant instability, but a preferred Planetary Boundary Layer low-level convergence zones tied to the orography. As a result of this analysis two different kinds of circulations associated to recurrent convergence zones have been recognized: upvalley/upslope winds and sea breezes.

High resolution simulations from a Numerical Weather Prediction model for a case study have carried out to analyze the role of the main key components, i.e. the orography, the sea and valley breeze and their influence to generate local convergence zones. Furthermore, the skills of the model to simulate the location and the intensity of the precipitation of these summer Mediterranean storms have been discussed.
\end{abstract}

\section{Introduction}

The Mediterranean Pyrenees or Eastern Pyrenees (red dotted rectangle in Fig. 4) show a high frequency of afternoon convective storms during summertime with more than 30 days (Terradelles, 1996; Vilar, 2000). This fact determines a particular seasonal rainfall regime with a summer maximum and a winter minimum unlike the normal and general summer minimum over Mediterranean basin. As is shown by Terradelles $(1996,1997)$ there is a relative maximum of lightning density at this season as well, tied up to afternoon convection. Furthermore, in previous studies carried out in

Correspondence to: A. Callado

(acallado@inm.es)
Catalonia (Pascual et al., 2004) Eastern Pyrenees are recognised as one of the very high convective areas as shown in his Fig. 1. It has been suggested that this maximum thunderstorms density could be related to the proximity of Mediterranean Sea: while upslope could play the role of triggering convection, sea breeze could supply additional moisture (Terradelles, 1997; Pascual et al., 2004). The main goal of this study is to investigate these hypotheses.

For simplicity we focus our interest 26 August 2003 because is a typical case with convection only in Eastern Pyrenees. It is important to remember that 2003 summer was characterised by dry and very warm conditions.

\section{Observational analysis and diagnosis}

The 26 August 2003 was characterised by a ridge and relatively warm air at $500 \mathrm{hPa}\left(-10^{\circ} \mathrm{C}\right)$ over Western Mediterranean. At low levels the main element was a thermal low centred at the Iberian Peninsula. No significant instability was present at synoptic scale.

As shown in Table 2 and Fig. 3 the data from Spanish Meteorological Service (INM) and Automatic System of Hydrologic Information (SAIH) from the Generalitat of Catalunya networks focused the precipitation in Eastern Pyrenees with a maximum over Ripollès region and a secondary one in Berguedà region. The maximum rainfalls reported were around $35-40 \mathrm{~mm}$.

Radar reflectivity imagery and outputs from convective cells identification and tracking objective algorithm, operational on the INM (Martín, 2001), have been used to analyse convection development, evolution and propagation.

The first convective cell identified (11:40 UTC) developed over a mountainous area located between the upper Ter river valley (west-east oriented turning left to north-south) and the headwaters of two tributaries of the Fluvià river (eastwest oriented). An enhanced convergence area between upvalley/upslope western flow and an upslope eastern flow (combination of the mountain breeze circulation and the sea 

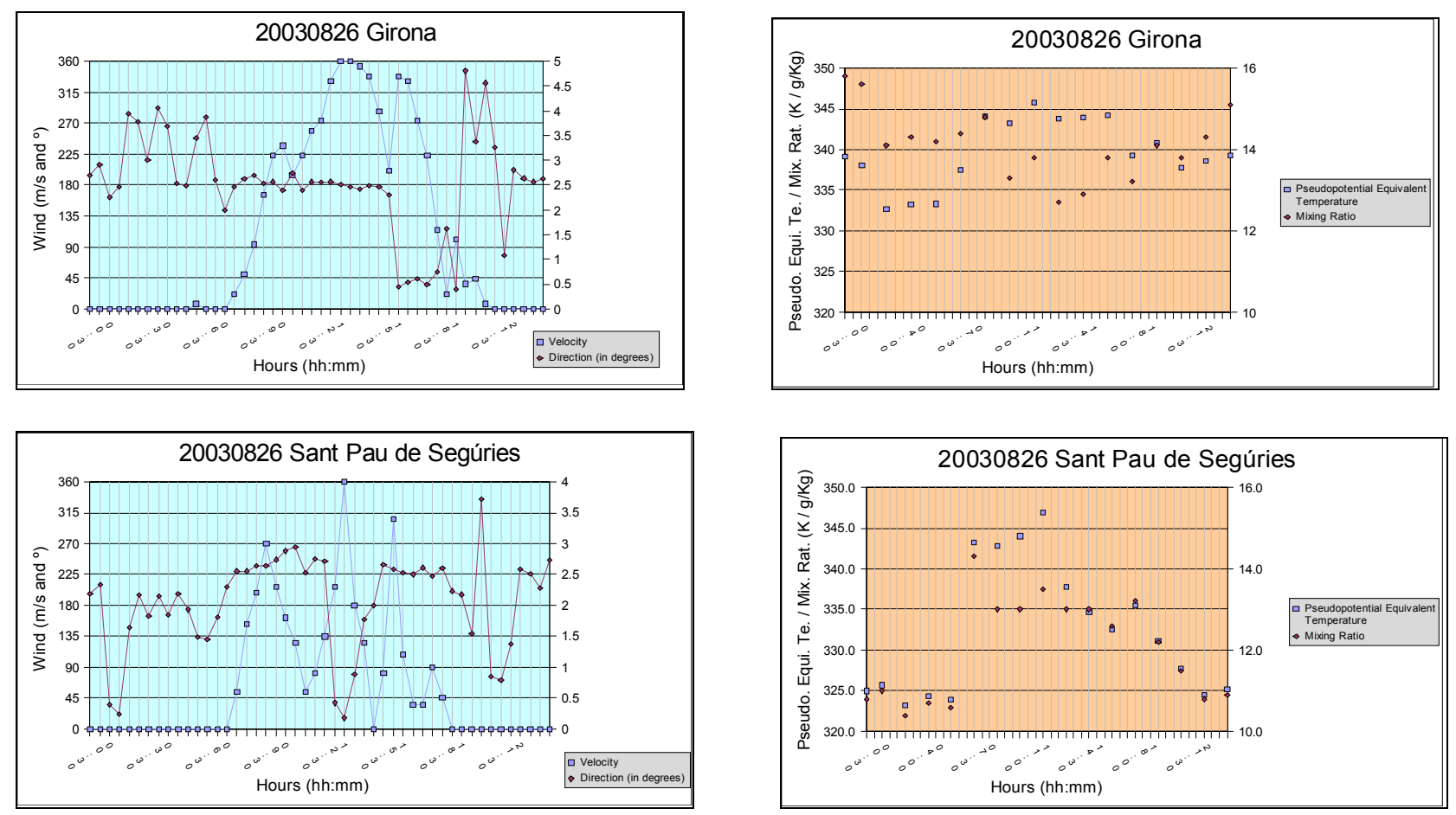

Fig. 1. Wind velocity and direction, pseudopotential equivalent temperature and mixing ratio for meteorological stations of Girona and St. Pau de Segúries (dataset Servei Meteorològic de Catalunya or SMC).

Table 1. Main features of simulations and experiment design.

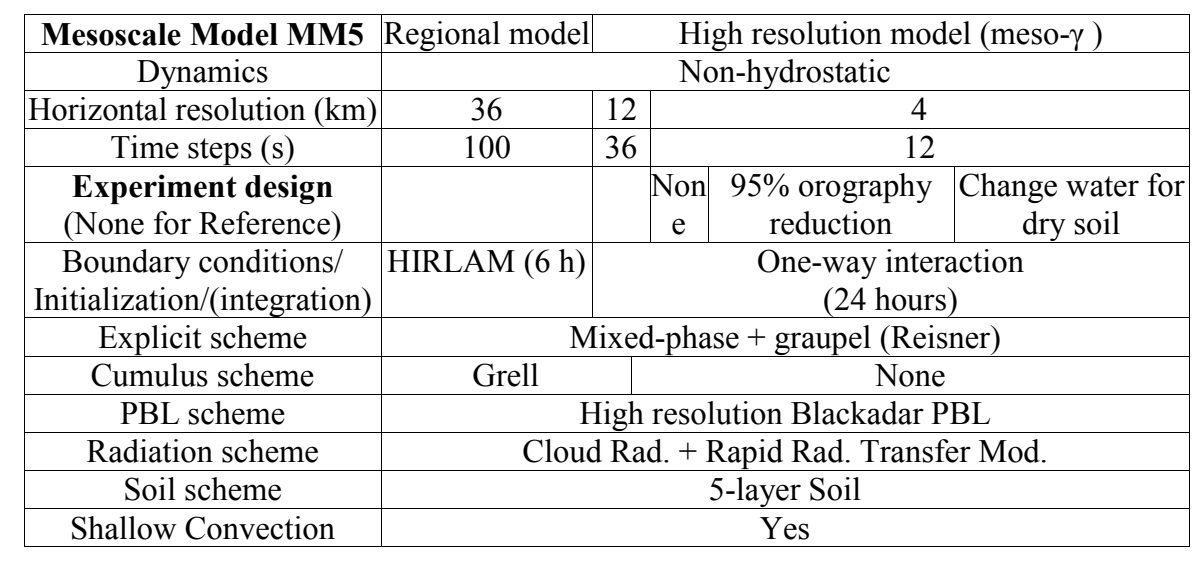

breeze channelled by Fluvià valley) could be the main mechanism that triggered this first convective cell. This area is located $50 \mathrm{~km}$ from the coastline.

Radar reflectivities higher than $50 \mathrm{dBZ}$ persisted during the next $4 \mathrm{~h}$ showing an organization of the convection, with a maximum value of $60 \mathrm{dBZ}$ at 15:50 UTC probably associated to hail. Interaction between outflows and sea breeze are probably the main mechanisms to triggering new convection and developing new thunderstorms. Thunderstorms southward propagation is the consequence of the combination of the translation component associated to the northern flow at middle levels (eastern branch of the synoptic ridge). After 13:50 UTC a new convective cells were developed at the headwaters of the two slopes of Eastern Pyrenees.

Surface observations (mainly wind velocity and direction) show that sea breezes were well developed along the coastline, and synoptic conditions suggest that valley breezes and upslope circulations were also present over the main ranges. Air mass characteristics (mixing ratio about $13 \mathrm{~g} / \mathrm{kg}$ and pseudopotential equivalent temperature of about $345 \mathrm{~K}$ ) were very similar in coastal stations and Eastern Pyrenees, which agrees with the hypothesis sea breezes blow inland over the 

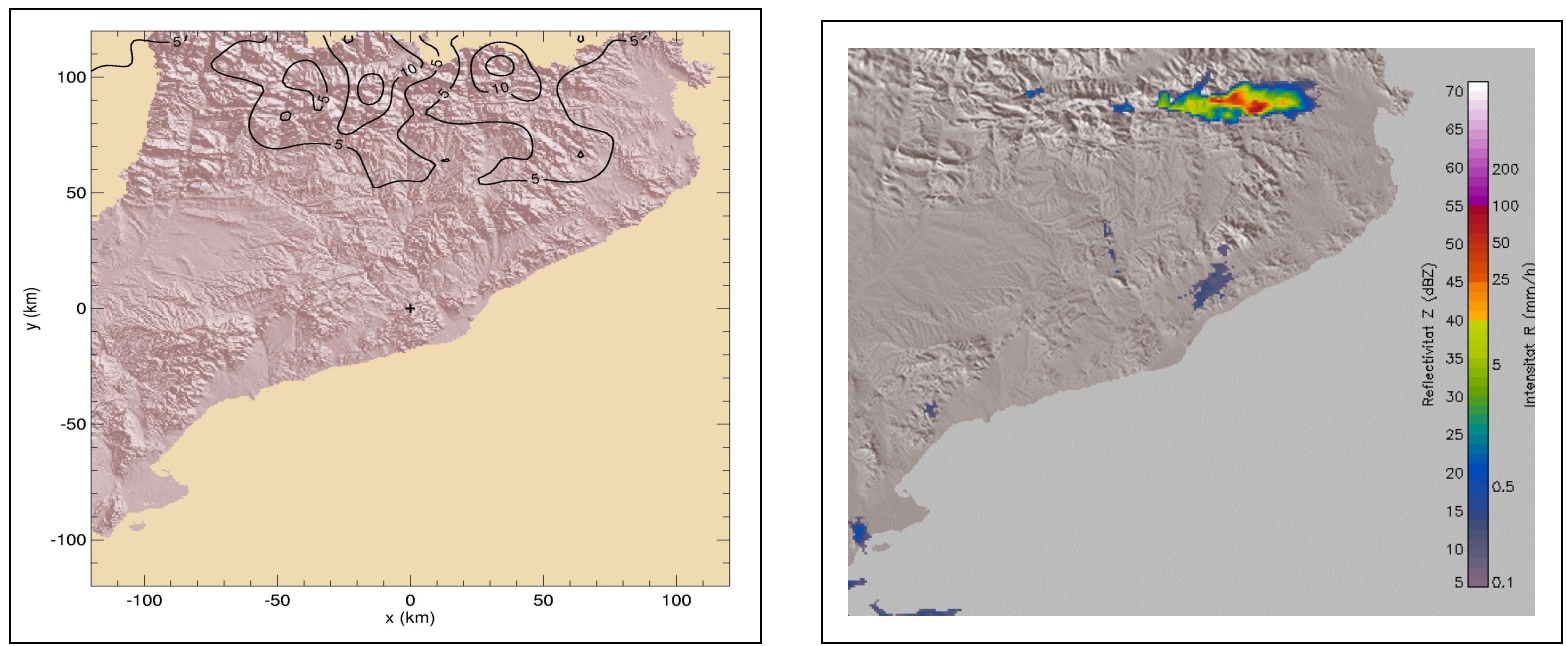

Fig. 2. (a) Relative frequency (\%) of radar reflectivity echo values equal or greater than $35 \mathrm{dBZ}$ at 15:00 UTC for June, July and August 2003; (b) Radar reflectivity image (dBZ) of 26 August 2003 at 13:30 UTC.

Table 2. Precipitations reported by raingauge on 25 August2003. Locations in Fig. 3.

\begin{tabular}{lll}
\hline Data provided by & Precipitations (mm) and raingauge & \\
\hline CMTC (INM) & 25.0 Vall de Bianya (VB) & 38.0 Vidrà (V) \\
32.0 Castellfollit de la Roca (CR) & 37.6 Collfred (C) & \\
SMC & 35.0 Sant Pau de Segúries (PS) & \multirow{2}{*}{ 5.8 Molló (M) } \\
11.0 Olot (O) & 3.8 Núria (N) & \\
SAIH & 35.2 Sant Joan de les Abadesses (JA) & 33.7 Bagà (B) \\
21.3 Castellar de N'Hug (CN) & & \\
\hline
\end{tabular}

Table 3. Peak and total integrated Quantitative Precipitation Forecast (QPF).

\begin{tabular}{lcc}
\hline Data & Peak $(\mathrm{mm})$ & Total QPF $\left(10^{6} \mathrm{l}\right)$ \\
\hline Observed (raingauge) & 38.0 & None \\
Gridding observed & 32.0 & 41958.7 \\
Forecast 4 km (12:00 to 15:00 UTC) & 41.8 & 43668.7 \\
Forecast 4 km (12:00 to 18:00 UTC) & 70.2 & 140725.3 \\
\hline
\end{tabular}

Empordà plain from the Gulf of Roses and are channelled upstream by the main valleys. Upvalley winds (Ter and Fluvià valleys) also developed and their coupling enhanced upslope circulations and convergence at the headwaters.

\section{Numerical simulations}

In order to analyze the role of the main key components, i.e. the orography, the sea and upvalley breeze and their influence to generate local convergence zones, several numerical simulations have been conducted using the Pennsylva-

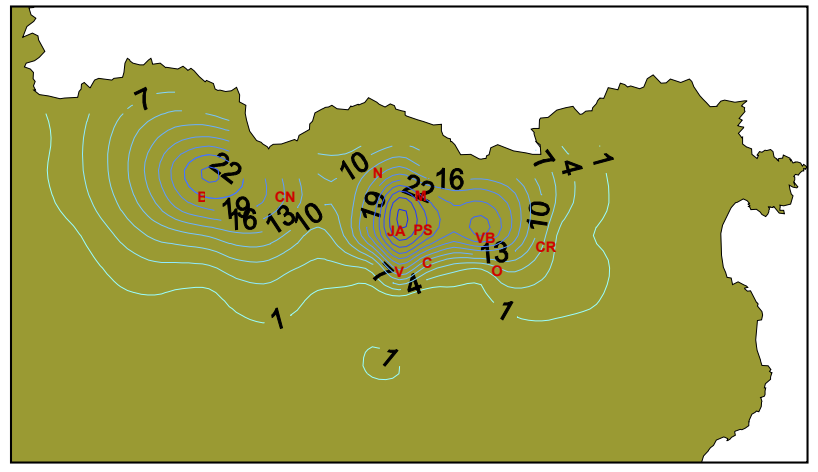

Fig. 3. Kriged precipitation from INM and SAIH networks.

nia State University-National Center for Atmospheric Research mesoscale non-hydrostatic model version 3.5 (MM5) running with one-way triply nested grids from meso- $\beta$ to meso- $\gamma$ scales (domains with horizontal resolutions of 36 , 12 and $4 \mathrm{~km})$. Simulations characteristics are summarized in Table 1.

In general, there is a good agreement between the simulated precipitation field at $4 \mathrm{~km}$ and raingauge observations and radar imagery (compare Fig. 2b, 3 and 4). Furthermore 

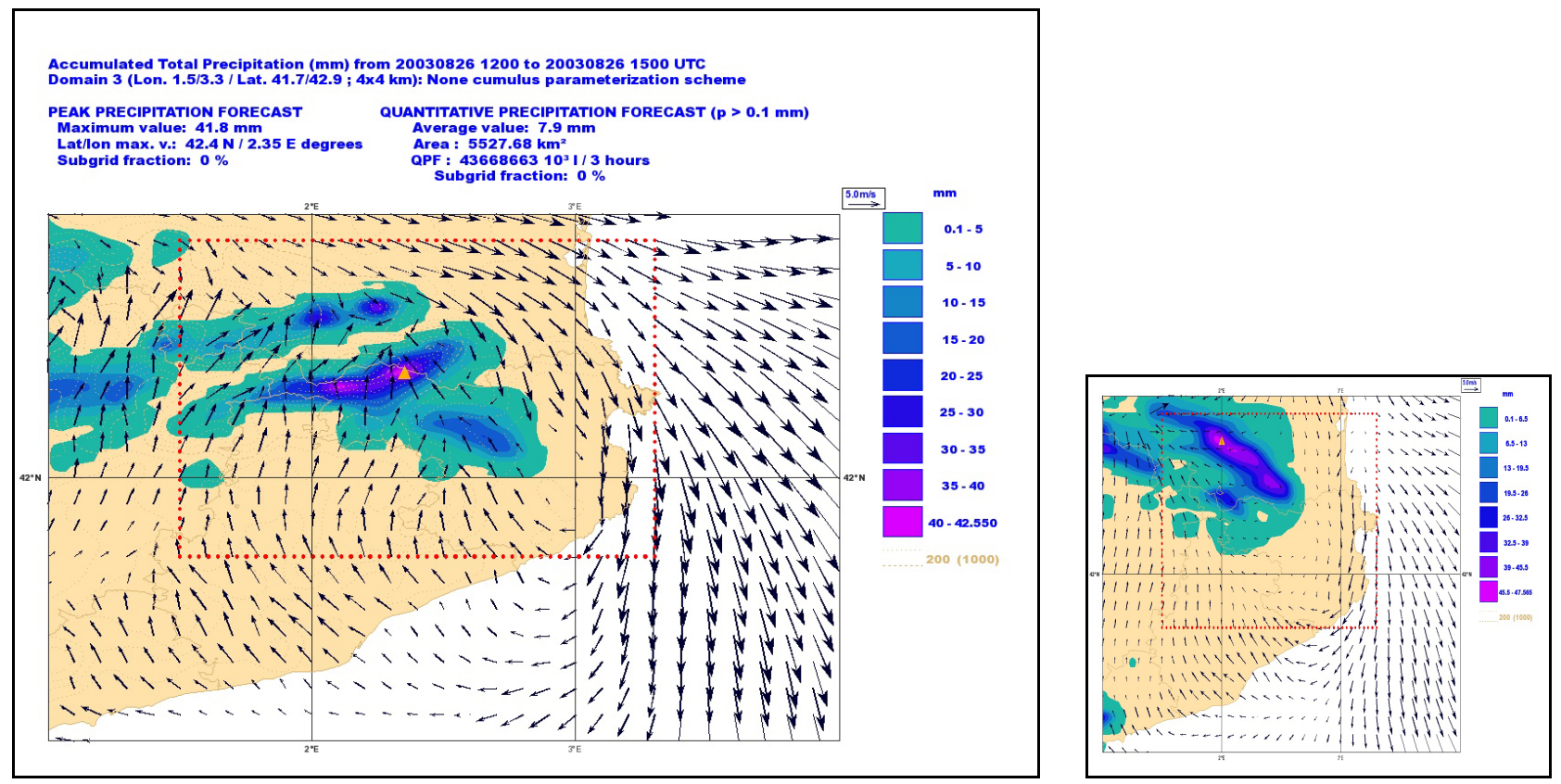

Fig. 4. (a) Quantitative Precipitation forecast and winds at interval time 12:00-15:00 UTC; (b) The same forecast with 95\% orography reduction.

timing and location of the simulated convection adjust well with observations of thunderstorm development at both slopes of Pyrenees as with the development of new cells southward of first generation cell. In particular it is worth noting that the location and amount of peak and total integrated Quantitative Precipitation Forecast (QPF) agree (slight higher) with observations between 12:00 UTC and 15:00 UTC, as we can see in Table 3. After 15:00 UTC the simulations show an excessive precipitation associated to the second convection generation, possibly related to an excess of humidity availability in boundary conditions.

Surprisingly simulation of breeze at Gulf of Roses failed, but in spite of this fact the experiment reproduces a moisture convergence zone (not shown) between hypothetical upvalley Ter and tributaries of Fluvià breezes (see Sect. 2).

With the aim of evaluating the role of key components in the triggering and development of convection in the Eastern Pyrenees two more $4 \mathrm{~km}$ resolution simulations were performed with:

1. A 95\% orography reduction in order to evaluate the role of sea and upvalley breezes and upslope winds (Fig. 4b); and

2. A transformation of the Mediterranean Sea (moisture available 100) to a dry land (moisture available 30) to find out the role of sea breezes supplying moisture to the convection generated.

The first one shown that the sea breezes appears as well, but they go so further inland and converge with eastward Atlantic flow. A very similar total QPF was obtained, but displaced $40-60 \mathrm{~km}$ to the north and delayed $3 \mathrm{~h}$. Moreover the breeze appears later and weaker; this fact may be in agreement with the supposition that upvalley and sea breezes are coupled increasing the flow strength.

Surprisingly the second one is quite similar to the reference simulation between 12:00 UTC and 15:00 UTC. Lateral boundary conditions generated a sea breeze into the domain flowing over flat terrain as far as Eastern Pyrenees. Although the development of upvalley breezes would be the same, they appear slight weaker due to the weaker sea breeze showing once again the linking role between sea and mountain breezes.

\section{Conclusions}

The development of thunderstorms over the Eastern Pyrenees under anticyclonic and relatively stable conditions has been analyzed using surface observations, radar imagery and simulations of a mesoscale numerical weather prediction model.

From this analysis it is possible to suggest some mechanisms that could explain the high frequency of convective storms over this area in late spring and summer related to the local orography and maritime influence:

1. The maximum frequency of storms in the afternoon is associated to the diurnal cycle with the intense development of upvalley and slope circulations and sea breezes (Terradelles, 1997);

2. The orography plays an important role generating local convergence zones and channelling the sea breezes following the main valleys; 
3. The coupling between upvalley and sea breezes supply an extra moisture at low levels that could explain the higher frequency of thunderstorms in this area in comparison with Western Pyrenees where sea breezes can not reach to the headwaters of the tributaries of the Ebro river;

4. A low level local moisture convergence, between western Ter upvalley breeze and eastern tributaries Fluvià upvalley breezes linked to Gulf Roses breeze, is identified triggering recurrent summertime convection.

Acknowledgements. The authors thanks to the Spanish Instituto Nacional de Meteorología for providing data and support and Departament d'Astronomia i Meteorologia of Barcelona University for providing SAIH data.

Edited by: L. Ferraris

Reviewed by: V. Kveton and another referee

\section{References}

Martín, F.: Identificación objetiva de estructuras convectivas a partir de los datos radar del PPI/CAPPI bajo en MCIDAS [CD-ROM], V Simposio Nacional de Predicción, Instituto Nacional de Meteorología (INM), Madrid (Spain), 20-23 November 2001.

Pascual, R., Callado, A., and Berenguer, M.: Convective storm initiation in central Catalonia, Third European Conference on Radar in Meteorology and Hydrology (ERAD), Visby, Island of Gotland (Sweden), 6-10 September 2004, ERAD Publication Series, 2, 464-468, 2004

Terradelles, E.: Focalización de la convección estival en Cataluña, IV Simposio Nacional de Predicción, Instituto Nacional de Meteorología (INM), Madrid (Spain), 15-19 April 1996, pp. 133-142. 1996.

Terradelles, E.: Main features of the distribution of the atmospheric electric activity in Catalonia and the surrounding Mediterranean area, INM/WMO International Symposium on Cyclones and Hazardous Weather in the Mediterranean, Palma de Mallorca (Spain), 14-17 April 1997, pp. 535-540, 1997.

Vilar, F.: Situaciones, riesgos y recurrencia de tormentas intensas en el Pirineo Oriental, Situaciones de Riesgo Climático en España, II Reunión del Grupo de Climatología de la Asociación de Geógrafos Españoles, 15-17 September 1995, pp. 105-116, 1995. 